\title{
Impact of foreign institutional and individual ownership on stock return volatility in Indonesia
}

\author{
Pima V. Tresna \& Irwan A. Ekaputra \\ Department of Management, Faculty of Economics and Business, Universitas Indonesia, Depok, Indonesia
}

\begin{abstract}
This research examines the impact of foreign institutional and individual ownership on the one step ahead monthly stock return volatility. This research uses monthly data of foreign and domestic ownerships from the Kustodian Sentral Efek Indonesia (KSEI) database. This study employs Fama-MacBeth cross-sectional regression based on Rhee and Wang (2009). The results of this research indicate that foreign institutional ownership lowers future stock return volatility. Meanwhile, foreign individual ownership increases future stock return volatility. Changes of foreign institutional and individual ownerships also display consistent results with the level of foreign institutional and individual ownerships. Further investigations that separate foreign institutional ownership from foreign financial institutional ownership and non-financial institutional ownership indicate that foreign non-financial institutional ownership consistently lowers future stock return volatility. Meanwhile, foreign financial institutional ownership exhibits mixed results.
\end{abstract}

\section{INTRODUCTION}

Many studies about capital market liberalization have been done in the past years in many points of views. One of the studies examines the impact of capital market liberalization on variability of stock returns. Variability of stock return, or known as stock return volatility, has an important role in emerging capital market. Many investors use capital market volatility as one of determinants in making investment decisions because high volatility in capital market is equal with a high cost of capital. Additionally, high volatility is also considered equal with high instability in capital market (Bekaert and Harvey, 1997).

At first, much of the research about the impact of capital market liberalization on stock return volatility was conducted by event studies. Event studies were done by examining changes of volatility on the period before, during and after capital market liberalization. However, the type of the event studies of research only examines one period of time that is not enough to describe the impact of capital market liberalization on stock return volatility. This is because the process of capital market liberalization not only occurs in one period of time but also occurs gradually (Bae et al., 2004).

After the type of the event studies of research, the research is developed into panel studies. One of the panel studies includes research about the impact of foreign investor investability on stock return volatility (Bae et al. 2004). It is assumed that the higher degree the foreign investor investability, the higher degree the capital market liberalization in that country (Bae et al., 2004).

After the type of the event studies of research, the research is developed into panel studies. One of the panel studies includes research about the impact of foreign investor investability on stock return volatility (Bae et al., 2004). It is assumed that the higher degree the foreign investor investability, the higher degree the capital market liberalization in that country (Bae et al., 2004).

Foreign investor investability is the maximal percentage of foreign ownership that is allowed in one country's capital market. However, foreign investor investability cannot fully 
represent capital market liberalization in one country. There are possibilities that one firm stock has a high degree of foreign investor investability, but it has a low percentage of foreign ownership. Increasing firm stock investability does not directly increase foreign ownership in that stock (Li et al., 2011).

Because foreign ownership cannot fully represent capital market liberalization in one country, research is developed further by using another variable as the proxy for capital market liberalization. Another variable that is considered sufficient to represent capital market liberalization is foreign ownership. Different from foreign investor investability, the percentage of foreign ownership of firm stock represents the actual proportion of foreign ownership. The higher the foreign ownership percentage in one country capital market, the higher the foreign investor participations and activities at the capital market are (Li et al., 2011).

The first research about the impact of foreign ownership on stock return volatility was done by Li et al. (2011). Li et al. (2011) did research by using Large Foreign Ownership (LFO) as a proxy for capital market liberalization. As further examination, Li et al. (2011) also categorized LFO into large foreign ownership in financial institution and non-financial institution. Li et al. conclude that examining heterogeneity and understanding each role of foreign investors are important.

Stiglitzt (2000) also emphasizes the importance of examining heterogeneity of foreign investors in capital markets. Stiglitz (2000) highlights the importance of examining the impacts of various types of capital flows coming into capital markets. One of the types of capital flows is various categories of foreign investors in capital markets. If the role of each category of foreign investors is already known, it is expected to provide different treatment tailored to the role of each category of foreign investors.

This research refers to the importance of knowing the impact of heterogeneous foreign investors on stock return volatility. Heterogeneous foreign investors are further categorized into foreign institutional and individual investors. Additionally, to examine the impact of foreign institutional investor heterogeneity, foreign institutional investors are also further categorized into foreign financial institution investors and foreign non-financial institution investors, and we examine its impact on stock return volatility. Thus, this research aims to examine the impact of foreign institutional and individual ownership on stock return volatility.

\section{MAIN HYPOTHESES}

Institutional and individual ownership is assumed to have different characteristics and impacts on capital markets. Stiglitz (2000) conveys arguments where long-term investments from Foreign Direct Investment (FDI) provide a stabilizing impact on capital market's volatility. This is because foreign investors who are doing long term investment in a country not only provide the flow of funds but also provide technology, access to global markets, and improved human resources. Meanwhile, short-term investments by foreign investors give impact on increasing the volatility of the capital markets.

Stiglitz (2000) argues that the short-term investment by foreign investors is an unstable form of investment due to information imbalance for foreign investors. In addition, due to lack of attachment between companies and short-term foreign investors, this can lead to foreign investors easily withdrawing funds from the capital market if the economic condition is declining.

The results of research conducted by Li et al. (2011) show that foreign institutional investors give negative impacts or stabilize stock return volatility. Li et al. (2011) argue that foreign institutional investors have similar characteristics as the characteristics of Foreign Direct Investment (FDI). Based on above arguments, the first hypothesis for this research is described as follows:

Hypothesis-1: Foreign institutional ownership gives an impact that stabilizes stock return volatility in Indonesian capital market.

Meanwhile, according to the research conducted by Foucault et al. (2011), I ndividual investors's trading activities give a positive impact or increase stock return volatility in 
Euronext Paris capital market. Foucault et al. (2011) argue that individual or retail investors have a role as noise traders in the capital market. Although individual investors who use the kontrarian strategy are supposed to stabilize the capital market volatility, the capital market stabilizing effect is covered by volatility increasing the effect that occurs with momentum trading by individual investors.

This argument is also corroborated by the research conducted by Barber and Odean (2009) who found that the herding behavior of individual investors increases volatility in the United States capital market. Meanwhile, Chen et al. (2013) found that the trading activity by foreign investors leads to fluctuations on the capital markets of developing countries. Chen et al. (2013) found that individual investors are less rational and tend to give an excessive reaction to news and circulation of market information. Based on the above arguments, the second hypothesis for this research is described as follows:

Hypothesis-2: Foreign individual ownership gives an impact that increases stock return volatility in Indonesian capital market.

\section{DATA}

This research uses the following data: Foreign and domestic investor ownership of firm's stocks that are listed on Indonesian Stock Exchange (IDX) since the enactment of SID (Single Identity Investor) regulation i.e. February 2012-January 2015 are obtained from the Indonesian Central Securities Depository (KSEI) database. In addition, this research uses the stock price, market capitalization, transaction value, the number of shares outstanding, the interim financial statements of companies listed on the Indonesian Stock Exchange (IDX) since the enactment of the SID (Single Investor Identity) regulation i.e. February 2012-January 2015 obtained from Thomson Reuters database.

\section{VARIABLES}

\subsection{Dependent variables}

On this research, the firm's stock return volatility is represented by two proxies. Two of these proxies are monthly Standard Deviation (SD) of stock returns volatility and volatility of stock returns based on Chen et al. (2013) and Li et al. (2011). The formula of the monthly Standard Deviation (SD) calculation used in this research is as follows:

$$
S D_{i}=\sqrt{\frac{\sum\left(x_{i, t}-\overline{x_{i, t}}\right)^{2}}{(T-1)}}
$$

where $x_{i, t}$ is daily stock return in one month period, $\overline{x_{i, t}}$ is average daily stock return in one month period, and $\mathrm{T}$ is the sum of stock return in one month period.

The formula of monthly Volatility calculation used in this research is as follows:

$$
V L_{l}=\frac{1}{T} \sum \ln \left(x_{i, t}^{2}\right)
$$

where $x_{i, t}$ is daily stock return in one month period, and $\mathrm{T}$ is the sum of stock trading day in one month period.

\subsection{Independent variables}

Because this research aims to examine the impact of foreign institutional and individual investor ownership, the independent variable used in this study is monthly foreign ownership 
which is divided into foreign institutional ownership (FORINST) and foreign individual ownership (FORIND). Given the importance of knowing the impact of foreign investors that are heterogeneous, Li et al. (2011) further divide foreign institutional investors into foreign financial institution investors and foreign non-financial institutions investors. Similar to Li et al. (2011), this research also divides foreign institutional ownership into foreign financial institution ownership (FOREIGN_FIN) and foreign non-financial institution ownership (FOREIGN_NONFIN).

\subsection{Control variables}

In accordance with the research conducted by Chen et al. (2013) and Li et al. (2011), this research also uses several control variables including the following: Lagged stock return volatility (Lag (SD) and Lag (VL); Domestic ownership; Firm size (SIZE), which is measured as natural logarithm of market capitalization of stock market value in one month period; Turnover (TURNOVER), measured as monthly transaction value divided by its market capitalization; Leverage ratio (LEVERAGE), measured as total liabilities divided by a total asset taken from firm's interim financial statements.

\subsection{Interaction variables}

Similar to the research conducted by Rhee and Wang (2009), in addition to examine the impact of each independent and control variables on stock return volatility separately, this research also uses an interaction variable between an independent variable and a control variable. The interaction variables used are interaction between foreign ownership (FORINST and FORIND) and firm's size (SIZE) or stock turnover (TURNOVER). By examining the impact of interaction between foreign ownership and firm's size or stock turnover, it can be known the combined impact which is not visible if we examine the impact of foreign ownership and firm's size or stock turnover separately (Rhee and Wang 2009).

\section{$4.5 \quad$ Non-Linear variables}

Similar to the research conducted by Rhee and Wang (2009), this research also adds the nonlinear variable as a regressor. The non-linear variables used are the squared form of foreign ownership and domestic ownership. The aim for this addition is to examine the non-linear impact of foreign ownership on stock return volatility.

\section{METHODOLOGY}

Generally, the method implemented in this research refers to the method used by Rhee and Wang (2009) and Wang (2013). To examine the causality impact of foreign ownership on stock return volatility, this research performed regression using foreign institutional and individual ownership during one month period before stock return volatility as an independent variable (Rhee and Wang, 2009). Cross-sectional regression was done for each month during the 36-month period using lagged foreign ownership (FORINSTi, $\mathrm{t}-1$ and FORINDi, $\mathrm{t}-1$ ) as independent variables. Meanwhile, present stock return volatility (SDi, t and VLi, t) is used as a dependent variables.

After each monthly regression has been performed, the average coefficient is calculated from the coefficient deriving from the 36-month period regressions. In the meantime, to find out the significance of the coefficient, according to Rhee and Wang (2009), the standard error (SE) is calculated using the modified Fama-Macbeth formula by Cochrane (2001). The following is the formula of the modified Fama-Macbeth standard error:

$$
S E=\frac{S D(\beta)}{\sqrt{T}}\left(\frac{1+\rho(1)}{1-\rho(1)}\right)
$$


Description: SE is modified Fama-Macbeth standard error by Cochrane $(2001) ; \operatorname{SD}(\beta)$ is the standard deviation of coefficients $(\beta)$ resulting from each month estimation; $T$ is the number of the months; $\rho(1)$ is the first-order auto-correlation of coefficients $(\beta)$ resulting from each month estimation.

Meanwhile, empirical models used in this research are as follows:

\subsection{Impact of foreign institutional and individual ownership on stock return volatility empirical model}

The following is the regression model to examine the impact of foreign institutional and individual ownership on stock return volatility:

$$
\begin{aligned}
\operatorname{VOLAT}_{i, t}= & \beta_{0}+\beta_{1} \operatorname{Lag}\left(\operatorname{VOLAT}_{i, t}\right)+\beta_{2} \text { FORINST }_{i, t-1}+\beta_{3} \text { FORIND }_{i, t-1} \\
& +\beta_{4} \operatorname{CONTROL}_{i, t-1}+\beta_{5} \operatorname{INTERACTION~}_{i, t-1}+\beta_{6} N O N \\
& -\operatorname{LINEAR}_{i, t-1}+\varepsilon_{i, t}
\end{aligned}
$$

Description: CONTROLi, $\mathrm{t}-1$ is the control variable on period $\mathrm{t}-1$; FORINSTi, $\mathrm{t}-1$ is the sum of foreign institutional ownership divided by shares outstanding on period $t-1$; FORINDi, $\mathrm{t}-1$ is the sum of foreign individual ownership divided by shares outstanding on period $\mathrm{t}-1$; INTERACTIONi, $\mathrm{t}-1$ is the interaction variable on period $\mathrm{t}-1$; NON-LINEARi, $\mathrm{t}-1$ is a non-linear variable on period $t-1$; VOLATi, $t$ is the standard deviation/volatility of daily stock return volatility in one month period of $t$.

\subsection{Impact of foreign financial institution and non-financial institution ownership on the stock return volatility empirical model}

The following is the regression model to examine the impact of the foreign financial institution and non-financial institution ownership on stock return volatility:

$$
\begin{aligned}
\text { VOLAT }_{i, t}= & \beta_{0}+\beta_{1} \operatorname{Lag}\left(\text { VOLAT }_{i, t}\right)+\beta_{2} \text { FOREIGN_FIN }_{i, t-1} \\
& +\beta_{3} \text { FORIENG_NONFIN }{ }_{i, t-1}+\beta_{4} \text { CONTROL }_{i, t-1}+\beta_{5} \text { INTERACTION }_{i, t-1} \\
& +\beta_{6} \text { NON }- \text { LINEAR }_{i, t-1}+\varepsilon_{i, t}
\end{aligned}
$$

Description: CONTROLi, $\mathrm{t}-1$ is the control variable on period $\mathrm{t}-1$; FOREIGN_FINi, $\mathrm{t}-1$ is the sum of foreign financial institution ownership divided by shares outstanding on period $\mathrm{t}-1$; FOREIGN_NONFINi,t-1 is the sum of foreign non-financial institution ownership divided by shares outstanding on period $t-1$; INTERACTIONi, $t-1$ is the interaction variable on period $\mathrm{t}-1$; NON-LINEARi,t-1 is the non-linear variable on period $\mathrm{t}-1$; VOLATi, $\mathrm{t}$ is the standard deviation/volatility of daily stock returns volatility in one month period of $t$.

\section{RESULTS AND ANALYSIS}

\subsection{The impact of foreign institutional and individual ownership on stock return volatility}

Table 1 is the results of regression that examines the impact of foreign institutional and individual ownership on stock return volatility.

According to model IC on Table 1, foreign institutional ownership gives a negative impact on future stock return volatility. This result corroborates the initial hypothesis where foreign institutional ownership is assumed to give a negative impact on stock return volatility. The result of this study is consistent with the research conducted by Li et al. (2011) and Wang (2013), but is not consistent with the research conducted by Chen et al. (2013) and Ekaputra (2015). 
Table 1. Regression results of the impact of foreign institutional and individual ownership on stock returns volatility (coefficients and standard errors).

\begin{tabular}{|c|c|c|c|c|}
\hline & \multicolumn{2}{|l|}{ Model 1A } & \multicolumn{2}{|l|}{ Model 1B } \\
\hline & SD & $\mathrm{VL}$ & SD & $\mathrm{VL}$ \\
\hline & (Std. Error) & (Std. Error) & (Std. Error) & (Std. Error) \\
\hline FORINSTi,t-1 & $\begin{array}{l}-0.0011 \\
(0.00084)\end{array}$ & $\begin{array}{c}-3.6 \mathrm{E}-05 \\
(0.0001)\end{array}$ & $\begin{array}{l}-0.002 \\
(0.00646)\end{array}$ & $\begin{array}{c}0.00042 \\
(0.00082)\end{array}$ \\
\hline FORINDi,t-1 & $\begin{array}{c}0.00102 \\
(0.00111)\end{array}$ & $\begin{array}{l}9.5 \mathrm{E}-05 \\
(0.0001)\end{array}$ & $\begin{array}{l}0.01672^{* *} \\
(0.00748)\end{array}$ & $\begin{array}{l}0.00162 * * \\
(0.00079)\end{array}$ \\
\hline FORINSTi,t-1*SIZEi,t-1 & & & $\begin{array}{r}8.8 \mathrm{E}-05 \\
(0.00042)\end{array}$ & $\begin{array}{l}-3 \mathrm{E}-05 \\
(5.7 \mathrm{E}-05)\end{array}$ \\
\hline FORINDi,t-1*SIZEi,t-1 & & & $\begin{array}{c}-0.001 * * \\
(0.00052)\end{array}$ & $\begin{array}{l}-9 \mathrm{E}-05^{*} \\
(5.2 \mathrm{E}-05)\end{array}$ \\
\hline \multirow[t]{4}{*}{$\mathrm{R}^{2}$} & 0.26296 & 0.20598 & 0.28865 & 0.24133 \\
\hline & \multicolumn{2}{|l|}{ Model 1C } & \multicolumn{2}{|l|}{ Model 1D } \\
\hline & SD & VL & SD & $\mathrm{VL}$ \\
\hline & (Std. Error) & (Std. Error) & (Std. Error) & (Std. Error) \\
\hline FORINSTi,t-1 & $\begin{array}{c}-0.0075^{* * *} \\
(0.00274)\end{array}$ & $\begin{array}{c}-0.00062^{* *} \\
(0.00027)\end{array}$ & $\begin{array}{l}-0.0073 \\
(0.0072)\end{array}$ & $\begin{array}{l}-0.0001 \\
(0.00089)\end{array}$ \\
\hline FORINDi,t-1 & $\begin{array}{l}0.00475^{* *} \\
(0.00219)\end{array}$ & $\begin{array}{l}0.00045^{* *} \\
(0.00022)\end{array}$ & $\begin{array}{l}0.02319^{* * *} \\
(0.00793)\end{array}$ & $\begin{array}{l}0.00222^{* * *} \\
(0.00084)\end{array}$ \\
\hline FORINSTi,t-1*SIZEi,t-1 & & & $\begin{array}{l}-7 \mathrm{E}-05 \\
(0.00036)\end{array}$ & $\begin{array}{l}-4 \mathrm{E}-05 \\
(5.4 \mathrm{E}-05)\end{array}$ \\
\hline FORINDi,t-1*SIZEi,t-1 & & & $\begin{array}{c}-0.0013^{* *} \\
(0.00051)\end{array}$ & $\begin{array}{l}-0.0001^{* *} \\
(5 \mathrm{E}-05)\end{array}$ \\
\hline$(\text { FORINSTi,t-1) })^{2}$ & $\begin{array}{l}0.00751^{* * *} \\
(0.00227)\end{array}$ & $\begin{array}{l}0.00068^{* * * *} \\
(0.00025)\end{array}$ & $\begin{array}{l}0.00875^{* * *} \\
(0.00229)\end{array}$ & $\begin{array}{l}0.00082^{* * * *} \\
(0.00027)\end{array}$ \\
\hline$\left(\right.$ FORINDi,t-1) ${ }^{2}$ & $\begin{array}{c}-0.0049^{*} \\
(0.00253)\end{array}$ & $\begin{array}{l}-0.00052^{* *} \\
(0.0002)\end{array}$ & $\begin{array}{l}-0.0039 \\
(0.00304)\end{array}$ & $\begin{array}{l}-0.0003 \\
(0.00023)\end{array}$ \\
\hline $\mathrm{R}^{2}$ & 0.27229 & 0.21595 & 0.29832 & 0.25112 \\
\hline
\end{tabular}

Description: * two-sided significance at 10\%; ** two-sided significance at 5\%; *** two-sided significance at $1 \%$. SE (Standard Error) is re-calculated using the Cochrane (2001) method.

Li et al. (2011) give two arguments on why foreign institutional investors can give a stabilizing impact on stock return volatility of emerging countries' capital markets. The first argument is that foreign institutional investors have a commitment to their investments in the capital market and they aim to conduct long-term investment than short-term investment. Foreign institutional investors as shareholders give strong incentive in the form of financial assistance to the companies which have a reducing impact on stock return volatility.

The second argument is that foreign institutional investors have a supervision role towards the company. With its role of supervision, foreign institutional investors can pursue company's management transparency, more accountable management, and also a good risk management. In general, the increase of company performance can contribute to the decline of firm's stock return volatility.

In addition, Wang (2013) argues that foreign ownership could expand the investor basis of the company, so broader risk-sharing can give a decreasing impact on stock return volatility. Wang (2013) also argues that foreign investors do better supervision on the company than local investors, foreign analysts do a better analysis that local analysts, which causes the depletion of stock's information asymmetry. With reduced information asymmetry, it can give an impact on stabilizing stock return volatility. 
Meanwhile, according to models IB, IC, and ID of Table 1, foreign individual ownership gives a positive impact on future stock return volatility. This result also corroborates the initial hypothesis where foreign individual ownership is assumed to give a positive impact on stock return volatility. The result of this study is consistent with the research conducted by Foucault et al. (2011), but it is not consistent with the research conducted by Chen et al. (2013).

Foucault et al. (2011) argue that individual or retail investors have a role as noise traders in the capital market. Although individual investors who use the kontrarian strategy are supposed to stabilize the capital market volatility, the capital market stabilizing effect is covered by the volatility increasing effect that occurs with momentum trading by foreign investors. This argument is also corroborated by the research conducted by Barber and Odean (2009) who found that the herding behavior of individual investors increases volatility in the United States capital market.

Meanwhile, the regression results indicate that the interaction between foreign individual ownership and firms' size gives a negative impact on stock return volatility. Although lagged foreign individual ownership gives an increasing impact on stock return volatility, if the company has a large market capitalization, then it can reduce the increasing impact on the stock return volatility. Thus, it can be concluded that firm's size can help reduce the increasing impact of foreign ownership on stock return volatility.

Additionally, according to models IC and ID of Table 1, the non-linear variable of lagged foreign institutional ownership gives an increasing impact on stock return volatility. Similarly, according to models IC and ID of Table 1, the non-linear variable of lagged foreign individual ownership gives a decreasing impact on stock return volatility.

The result of this study corroborates the result of the research conducted by Wang (2013) where foreign institutional and individual ownership gives a non-linear impact on stock return volatility. The result of this research is also consistent with the result of the research conducted by Ekaputra (2015). It can be concluded that foreign institutional and individual ownership gives a non-linear impact on stock return volatility.

\subsection{The impact of the foreign financial institution and Non-Financial institution ownership on stock return volatility}

Estimation results of regression that examine the impact of foreign financial and non-financial institution investor ownership on future stock return volatility are presented in table 2 .

According to models $3 \mathrm{C}$ and $3 \mathrm{D}$ of Table 2, foreign financial institution ownership gives a stabilizing impact on future stock return volatility. However, model $3 \mathrm{~A}$ gives a different result where the result of regression shows that foreign financial institution ownership gives a destabilizing impact on future stock return volatility. Meanwhile, according to models $3 \mathrm{~B}$ and $3 \mathrm{D}$ of Table 2, foreign non-financial institution ownership gives a stabilizing impact on future stock return volatility. Thus, it can be concluded that foreign non-financial ownership gives a more consistent impact rather than foreign financial institution ownership.

These results are in line with the results of the research conducted by Li et al. (2011) where foreign non-financial institution investor ownership gives a more consistent impact in decreasing stock return volatility. Li et al. (2011) argue that foreign non-financial institution investors have a greater commitment in decreasing stock return volatility than foreign financial institution investors.

\section{ROBUSTNESS TEST}

In addition to regression using the level form of foreign institutional and individual ownership as the independent variable, this research also uses the change of the level form of foreign institutional and individual ownership. According to the research conducted by Rhee and Wang (2009), the aim of using the change of the level form of foreign ownership is to find out the impact of the change of foreign ownership in the past on stock return volatility. 
Table 2. Regression results of foreign financial and non-financial institution ownership on stock return volatility (coefficient and standard error).

\begin{tabular}{|c|c|c|c|c|}
\hline & \multicolumn{2}{|l|}{ Model 3A } & \multicolumn{2}{|l|}{ Model 3B } \\
\hline & \multirow{2}{*}{$\frac{\mathrm{SD}}{\text { (Std. Error) }}$} & \multirow{2}{*}{$\frac{\mathrm{VL}}{\text { (Std. Error) }}$} & \multirow{2}{*}{$\frac{\mathrm{SD}}{\text { (Std. Error) }}$} & \multirow{2}{*}{$\frac{\mathrm{VL}}{\text { (std. error) }}$} \\
\hline & & & & \\
\hline FOREIGN_FINi,t-1 & $0.00124^{*}$ & $0.00018^{* *}$ & 0.00035 & $\begin{array}{l}0.0007 \\
0.00055)\end{array}$ \\
\hline \multirow{2}{*}{ FOREIGN_NONFINi,t-1 } & $\begin{array}{l}(0.00071) \\
3 \mathrm{E}-06\end{array}$ & $\begin{array}{c}(8.3 \mathrm{E}-05) \\
1.6 \mathrm{E}-05\end{array}$ & $\begin{array}{l}(0.00382) \\
-0.0133 * * *\end{array}$ & $\begin{array}{l}(0.00055) \\
-0.0015 * * *\end{array}$ \\
\hline & $(0.00046)$ & $(6.8 \mathrm{E}-05)$ & $(0.00328)$ & $(0.00044)$ \\
\hline \multirow[t]{4}{*}{$\mathrm{R}^{2}$} & 0.26098 & 0.20466 & 0.28549 & 0.23803 \\
\hline & \multicolumn{2}{|l|}{ Model 3C } & \multicolumn{2}{|l|}{ Model 3D } \\
\hline & Coefficient & Coefficient & Coefficient & Coefficient \\
\hline & (Std. Error) & (Std. Error) & (Std. Error) & (Std. Error) \\
\hline FOREIGN_FINi,t-1 & $\begin{array}{c}-0.0065^{* *} \\
(0.00311)\end{array}$ & $\begin{array}{c}-0.0006^{* *} \\
(0.00029)\end{array}$ & $\begin{array}{c}-0.0092^{* *} \\
(0.00446)\end{array}$ & $\begin{array}{l}-0.0002 \\
(0.00045)\end{array}$ \\
\hline FOREIGN_NONFINi,t-1 & $\begin{array}{c}-0.0004 \\
(0.00311)\end{array}$ & $\begin{array}{l}-0.0001 \\
(0.00051)\end{array}$ & $\begin{array}{c}-0.0148 * * * \\
(0.00497)\end{array}$ & $\begin{array}{c}-0.0017^{* *} \\
(0.00084)\end{array}$ \\
\hline $\mathrm{R}^{2}$ & 0.27106 & 0.21697 & 0.29561 & 0.2502 \\
\hline
\end{tabular}

Description: * two-sided significance at 10\%; ** two-sided significance at 5\%; *** two-sided significance at $1 \%$. SE (Standard Error) is re-calculated using the Cochrane (2001) method.

In addition, using the change of the level form of foreign ownership in the regression is also aimed as a comparison to regression which uses the level form of foreign ownership (Rhee and Wang, 2009).

Generally, the result of the regression model which examines the impact to the change of the level form of foreign institutional and individual ownership on future stock return volatility supports the result of the previous regression model which used the level of foreign institutional and individual ownership as the independent variable (Table is available upon request). The regression results show that the change of the level form of foreign institutional ownership supports the previous results which show that the level form of foreign institutional ownership gives a stabilizing impact on future stock return volatility.

In addition, the change of the level form of foreign individual ownership also supports the previous regression model results which show that the level form of foreign individual ownership gives a destabilizing impact on future stock return volatility. Meanwhile, the regression model with the change of the level form of foreign financial institution and non-financial institution ownership also supports the regression model with the level form of foreign financial institution ownership as the independent variable.

\section{CONCLUSION}

The results of this research indicate that foreign institutional ownership lowers future stock return volatility. Changes of foreign institutional ownership display consistent results with the level of foreign institutional ownership. Meanwhile, foreign individual ownership increases future stock return volatility. Changes of foreign individual ownership also display consistent results with the level of foreign individual ownerships.

Further investigation that separates foreign institutional investors from foreign financial and non-financial institution investors displays that foreign financial institution investors give both stabilizing and destabilizing impacts on future stock return volatility. This result is 
supported by regression models which use the change of foreign financial institution investors as the independent variable.

Meanwhile, foreign non-financial institution ownership gives a stabilizing impact on future stock return volatility. This result is supported by the regression model using the change of foreign non-financial institution investors as the independent variable. Thus, it can be concluded that foreign non-financial institution ownership gives a more consistent impact than foreign financial institution ownership.

\section{REFERENCES}

Bae, Kee Hong, Kalok Chan, and Angela Ng. 2004. "Investibility and Return Volatility." Journal of Financial Economics 71 (2): 239-63. doi:10.1016/S0304-405X(03)00166-1.

Barber, Brad M., Terrance Odean, and Ning Zhu. 2009. "Do Retail Trades Move Markets?" Review of Financial Studies. 22(1): 151-186. doi:10.1093/rfs/hhn035.

Bekaert, Geert, and Campbell R. Harvey. 1997. "Emerging Equity Market Volatility.” Journal of Financial Economics 43 (1): 29-77. doi:10.1016/S0304-405X(96)00889-6.

Bekaert, Geert, Campbell R. Harvey, and Christian Lundblad. 2007. "Liquidity and Expected Returns: Lessons from Emerging Markets." Review of Financial Studies 20 (6): 1783-1831. doi:10.1093/rfs/ hhm030.

Brooks, Chris. 2008. Introductory Econometrics for Finance. Finance. doi:10.1111/1468-0297.13911.

Chari, Anusha, and P.B. Henry. 2001. "Stock Market Liberalizations and the Repricing of Systematic Risk." Working Paper. doi:10.3386/w8265.

Chen, Zhian, Jinmin Du, Donghui Li, and Rui Ouyang. 2013. "Does Foreign Institutional Ownership Increase Return Volatility? Evidence from China.” Journal of Banking and Finance 37 (2): 660-69. doi:10.1016/j.jbankfin.2012.10.006.

Cochrane, John H. 2001. Asset Pricing. Princeton University Press.

Ekaputra, Irwan Adi. 2015. "Foreign Institutional Ownership and Stock Return Volatility in Indonesia." Jurnal Keuangan Dan Perbankan, 19(3): 357-367.

Foucault, Thierry, David Sraer, and David J. Thesmar. 2011. "Individual Investors and Volatility." Journal of Finance 66 (4): 1369-1406. doi:10.1111/j.1540-6261.2011.01668.x.

Li, Donghui, Quang N. Nguyen, Peter K. Pham, and Steven X. Wei. 2011. "Large Foreign Ownership and Firm-Level Stock Return Volatility in Emerging Markets." Journal of Financial and Quantitative Analysis 46 (4): 1127-55. doi:10.2469/dig.v42.n2.44.

Rhee, S. Ghon, and Jianxin Wang. 2009. "Foreign Institutional Ownership and Stock Market Liquidity: Evidence from Indonesia.” Journal of Banking \& Finance 33 (7): 1312-24. doi:10.1016/j.jbankfin.2009.01.008.

Stiglitz, Joseph E. 2000. "Capital Market Liberalization, Economic Growth, and Instability." World Development 28 (6): 1075-86. doi:10.1016/S0305-750X(00)00006-1.

Wang, Jianxin. 2007. "Foreign Equity Trading and Emerging Market Volatility: Evidence from Indonesia and Thailand." Journal of Development Economics 84 (2): 798-811. doi:10.1016/j. jdeveco.2006.05.001.

Wang, Jianxin. 2013. "The Impact of Foreign Ownership on Stock Volatility in Indonesia." Asia-Pacific Journal of Financial Studies 42 (3): 493-509. doi:10.1111/ajfs.12022. 